\title{
Universiteit
}

Leiden

The Netherlands

\section{Women and disparities in leadership and wages}

Goharian, N.; Ma, X.; Verberne, S.

\section{Citation}

Goharian, N., Ma, X., \& Verberne, S. (2021). Women and disparities in leadership and wages. ACM SIGIR Forum (pp. 1-3). New York: ACM. Retrieved from https://hdl.handle.net/1887/3249378

Version: Publisher's Version

License: $\quad$ Leiden University Non-exclusive license

Downloaded from: https://hdl.handle.net/1887/3249378

Note: To cite this publication please use the final published version (if applicable). 


\title{
Women and Disparities in Leadership and Wages
}

\author{
Nazli Goharian \\ IR Lab, Georgetown University \\ nazli@ir.cs.georgetown.edu \\ Xin Ma \\ Microsoft Research Asia \\ xinma@microsoft.com \\ Suzan Verberne \\ Leiden Institute of Advanced Computer Science, Leiden University \\ s.verberne@liacs.leidenuniv.nl
}

\begin{abstract}
The SIGIR'20 Women in IR event, co-organized by SIGIR WIR co-chairs, Nazli Goharian and Suzan Verberne, and local co-chair of SIGIR'20 WIR, Xin Ma, took place on July 27-29 and was attended by 150 participants from different parts of the earth. Due to Covid-19, SIGIR'20 was held online. To accommodate all the time zones, we organized two sessions (A and B) on the same topics of discussion with two disjoint sets of panelists ${ }^{1}$, each group covering one of two sessions, totaling 19 panelists (17 female and 2 male) from academia and industry. This year we raised two questions for our panellists to discuss, followed by Q\&A by the audience. First we discussed the women's status as to holding key leadership roles both in the academia and industry. The second topic was gender inequity in pay, which we had already raised for the first time in our community in SIGIR'19 and was summarized in the WIR at SIGIR'19 Forum².
\end{abstract}

\section{Women and key leadership roles}

We opened the discussion by first presenting some statistics from Catalyst ${ }^{3}$, Pew Research Center ${ }^{4}$, Center for American Progress [Warner et al., 2018], and American Council on Education [Howard and Gagliardi, 2018] on the distribution of women and men in holding leadership roles such as college presidents (20-30\% women), CEO ( $6 \%$ women), CFO ( $12 \%$ women) and the governing boards ( $22 \%$ women) of fortune-500 companies. The reports of various sources indicated unbalanced distribution favoring males in these positions. The selection decisions on college presidents are reported to be influenced by businesses, the state, alumni, board of regents/trustee, and current internal powers. We also presented the distribution of women in the key leadership roles of our community of SIGIR, and reported 13\%,28\%,28\%,22\%,10\%,33\% distribution of women

\footnotetext{
${ }^{1}$ http://sigir.org/women-in-ir/sigir2020.html

${ }^{2}$ http://sigir.org/wp-content/uploads/2019/december/p044.pdf

${ }^{3}$ Women In Academia: Quick Take (2020); https://www.catalyst.org/research/women-in-academia

${ }^{4}$ The Data on Women Leaders (2018); https://www.pewsocialtrends.org/fact-sheet/the-data-on-wom en-leaders/
} 
in holding general chairs, program chairs of long-short papers, from 2016 to 2021, respectively, expecting conscious decision making within the SIGIR organization in the future. After providing these statistics, panelists were asked their points of view and how to address this issue and whether they find some variation of quota systems can be a solution among other solutions such as providing opportunities and support for women. The topic clearly was somewhat controversial, and various points of views and solutions were proposed. We summarize the sentiment of the sessions.

It was stated by the panelists that we are facing a 'leaky-pipeline' problem, namely the higher up in the organizational hierarchy, the smaller is the proportion of women; several solutions were addressed. Most prominently, the benefits and hindrances of quota systems were discussed. The negative sentiment was mainly based on the notion that quota-based hiring may disadvantage women by being regarded as not-merit based hiring. The opposing argument was that quotabased hiring must not be introspect to merit; examples are weighted quota where from a pool of qualified applicants the priority can be given to female candidates; other example is allocated hiring lines to hire women. When quotas are not allowed, alternatives are tie breakers based on gender, or group hires with diversity. Hence, neither of these are in contradiction with meritbased hiring, despite of being portrayed as such, at times. Among other solutions were the need for objective selection criteria for higher positions, and sponsorships for women; mentorship is important but does not replace sponsorship. Establishing prestigious awards for women was suggested as one of the actions to explicitly attribute accomplishments to women, who in turn can play as role models. It was expressed that lack of society's support in many countries for women by not offering sufficient maternity leave, child care support, elderly parent care, in addition to the existing hiring reluctance and bias against women are significant barriers for women in their professional advancement, many times forcing them to choose between personal and professional aspirations. Organizations should recognize the efforts of their employees in their efforts to expand diversity and reward them for doing such. Women in leading roles can and should be role models and advocates for other women in a pipeline that will increase the number of women in the leading roles. Establishing short term-limits of the key leadership roles in institutions can provide opportunity for female hires for those male dominant positions. At the end of the day it is not only the responsibility of women in this fight for equality but men too, when they make hiring decisions.

\section{Gender pay inequity}

On the topic of gender inequity in pay, the statistics from Catalyst ${ }^{5}$. Hired ${ }^{6}$, Forbes [Tarr, 2018], Inside Higher Ed [Seltzer, 2017], Eurostat ${ }^{7}$, The Harvard Crimson [Berger and McCafferty, 2019], The Daily Orange [Muller, 2019], The Chronicle of Higher Education [Hatch, 2017], and Pew Research [Graf et al., 2019] were presented indicating that female faculty receive $\sim 10-20 \%$ less than their male counterparts; female programmers receive $\sim 12 \%$ less than their male counterparts;

\footnotetext{
${ }^{5}$ Women's Earnings - The Pay Gap: Quick Take (2020); https://www.catalyst.org/research/womens-ear nings-the-pay-gap/

${ }^{6}$ The State of Wage Inequality in the Work (2018); https://hired.com/wage-inequality-report-2018

${ }^{7}$ Gender Pay Gap Statistics (2020); https://ec.europa.eu/eurostat/statistics-explained/index.php/G ender_pay_gap_statistics
} 
and female administrators at higher education are paid $\sim 20 \%$ less than their male counterparts. This was also somewhat of a controversial topic, and some raised doubts about the existence of this disparity. It was pointed out that promotion velocity is among the contributing factors to the wage gap. Among other factors, the initial salary at the time of the hiring was named, demanding the necessity of communities such as ours, SIGIR, to organize hiring workshops to provide female job seekers the salary scales and the art of negotiation, for those who these may be beneficial. The employers should be prohibited from asking for prior salary history of the applicants. The consensus was that as long as there is a lack of salary transparency, both the educational institutions and companies have easier time to continue with this pay inequity, hence, there should be a push for salary transparency.

\section{References}

Jonah S. Berger and Molly C. McCafferty. Female tenured harvard profs paid on average 92.5 cents on the dollar compared to men, survey shows. The Harvard Crimson, April 2019. URL https://www. thecrimson.com/article/2019/4/24/fas-pay-gap-2019/.

Nikki Graf, Anna Brown, and Eileen Patten. The narrowing, but persistent, gender gap in pay. Pew Research, March 2019. URL https://www.pewresearch.org/fact-tank/2019/03/22/g ender-pay-gap-facts/.

Joshua Hatch. Gender pay gap persists across faculty ranks. The Chronicle of Higher Education, March 2017. URL https://www.chronicle.com/article/gender-pay-gap-persists-acro ss-faculty-ranks/.

Elizabeth Howard and Jonathan Gagliardi. Leading the way to parity: Preparation, persistence, and the role of women presidents. American Council on Education, 2018. URL https://www . acenet.edu/Documents/Leading-the-Way-to-Parity.pdf.

Jordan Muller. Unsurprised - faculty react to report showing women professors earn less on average than men at syracuse university. The Daily Orange, 2019. URL http://dailyorange.com/20 18/02/unsurprised-faculty-react-report-showing-women-professors-earn-less-aver age-men-syracuse-university/.

Rick Seltzer. 80 cents on the dollar. Inside Higher Ed, February 2017. URL https://www . insi dehighered.com/news/2017/02/15/gender-pay-gap-persists-higher-education-admini strators.

Tanya Tarr. By the numbers: What pay inequality looks like for women in tech. Forbes, 2018. URL https://www.forbes.com/sites/tanyatarr/2018/04/04/by-the-numbers-what-pa y-inequality-looks-like-for-women-in-tech.

Judith Warner, Nora Ellmann, and Diana Boesch. The women's leadership gap. Center for American Progress, November 2018. URL https://www.americanprogress.org/issues/wo men/reports/2018/11/20/461273/womens-leadership-gap-2/. 